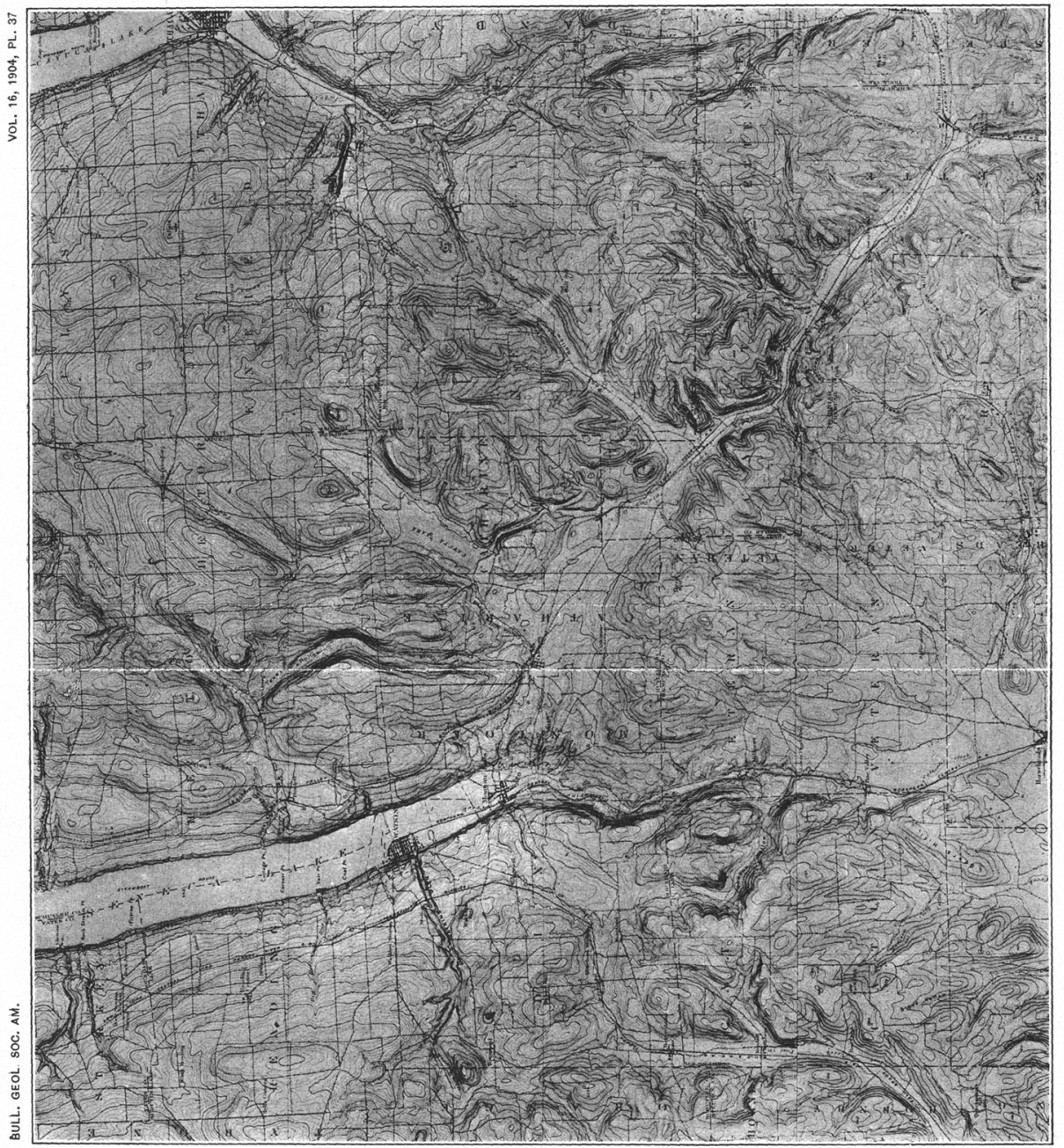




\title{
DRAINAGE FEATURES OF CENTRAL NEW YORK*
}

\author{
BY RALPH S. TARR
}

(Read before the Society December 30, 1904)

\section{CONTENTS}

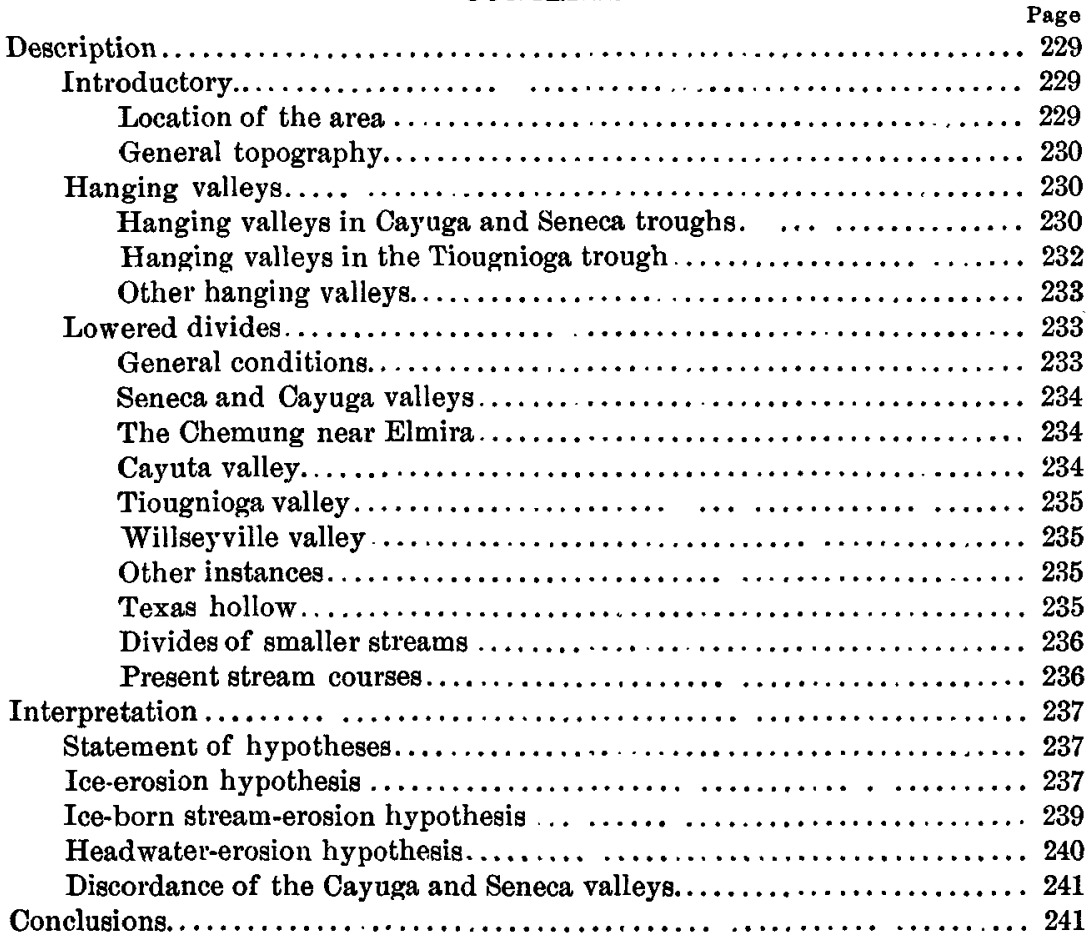

\section{DESCRIPTION}

INTRODUCTORY

Location of the area.-The region described in this paper is in southern central New York, along and near the divide between the Saint Lawrence

* Published by permission of the Director of the U. S. Geological Survey. 
and Susquehanna drainage systems. Most of the facts were obtained in studies leading to the preparation of the Watkins Glen Folio (see plate 37) of the United States Geological Survey, which includes the Ithaca, Watkins, Elmira, and Waverly topographic sheets; but some of the facts were discovered in the studies on the quadrangle east of the Watkins Glen.

General topography.*_The area under discussion is a part of the dissected Allegheny plateau, with uplands of mature form, deeply trenched by valleys of less mature character, whose sides are often too steep for farming and in some cases even precipices. In ruggedness of topography there is a difference from south to north, the northern portion being both evener and smoother than the southern. The uplands reach elevations of from 1,800 to 2,000 feet in a number of places, and even the smaller streams are in valleys whose bottoms are several hundred feet deep. The lowest known point in the region is the rock floor of the Seneca valley, which at Watkins is at least 637 feet below sealevel.

South of the divide, for the most part near the Pennsylvania state line, there is the long, deep Chemung-Susquehanna valley, extending east and west, with the united drainage from the two directions turning southward below Waverly. This is the largest valley in the area. North of the divide are north-south valleys, two of the largest of which are occupied by Cayuga and Seneca lakes. There are numerous smaller valleys tributary to one of these three major valleys, the largest having a general north-south direction, and most of them tributary to the Susquehanna system.

\section{HANGING VALLEYS}

Hanging valleys in Cayuga and Seneca troughs. $\dagger$-In both the Cayuga and Seneca valleys there is a change in valley slope at about the 900foot contour, the lower slope being much steeper than the upper (see plate 39, figure 2). This steepened slope extends to the bottom of the valley-that is, at least 850 feet in the Cayuga valley and from 1,400 to 1,500 feet in the Seneca valley. The region near Watkins may be taken as an illustration of this change in slope. From the 900 -foot contour just west of Watkins there is a slope down to the valley bottom of 1,400 feet in a little over a mile, while west of the 900 -foot contour the valley side rises only 700 feet in a distance of 5 miles.

Down to approximately this same level a series of valleys descend with moderate grade from the uplands; then the valleys change to gorges

\footnotetext{
* The text of the forthcoming Watkins Glen Folio contains a fuller and more complete discussion of the topography of this region.

† R. S. Tarr: American Geologist, vol. xxxiii, 1904, pp. 271-291.
} 


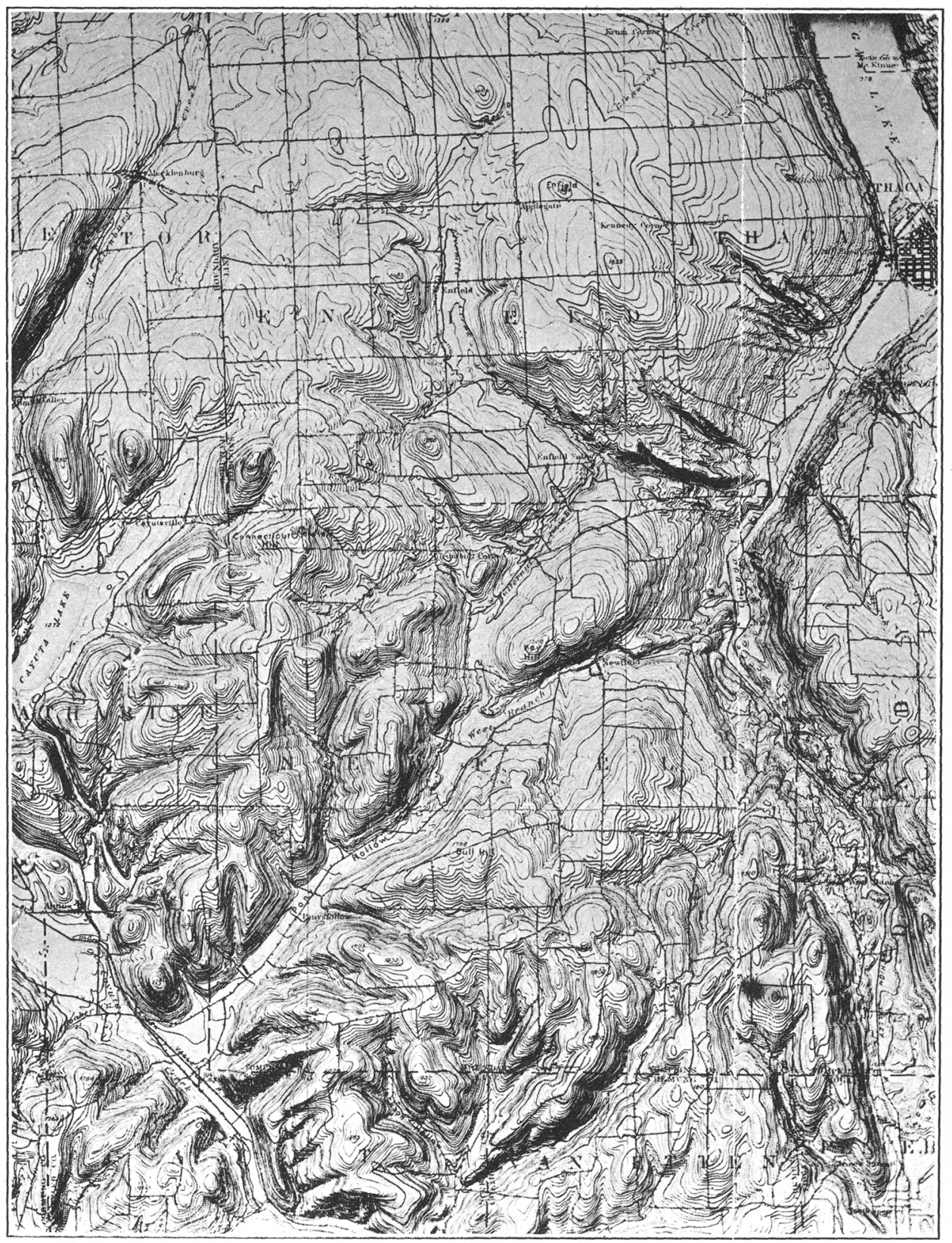

ITHACA TOPOGRAPHIC SHEET 


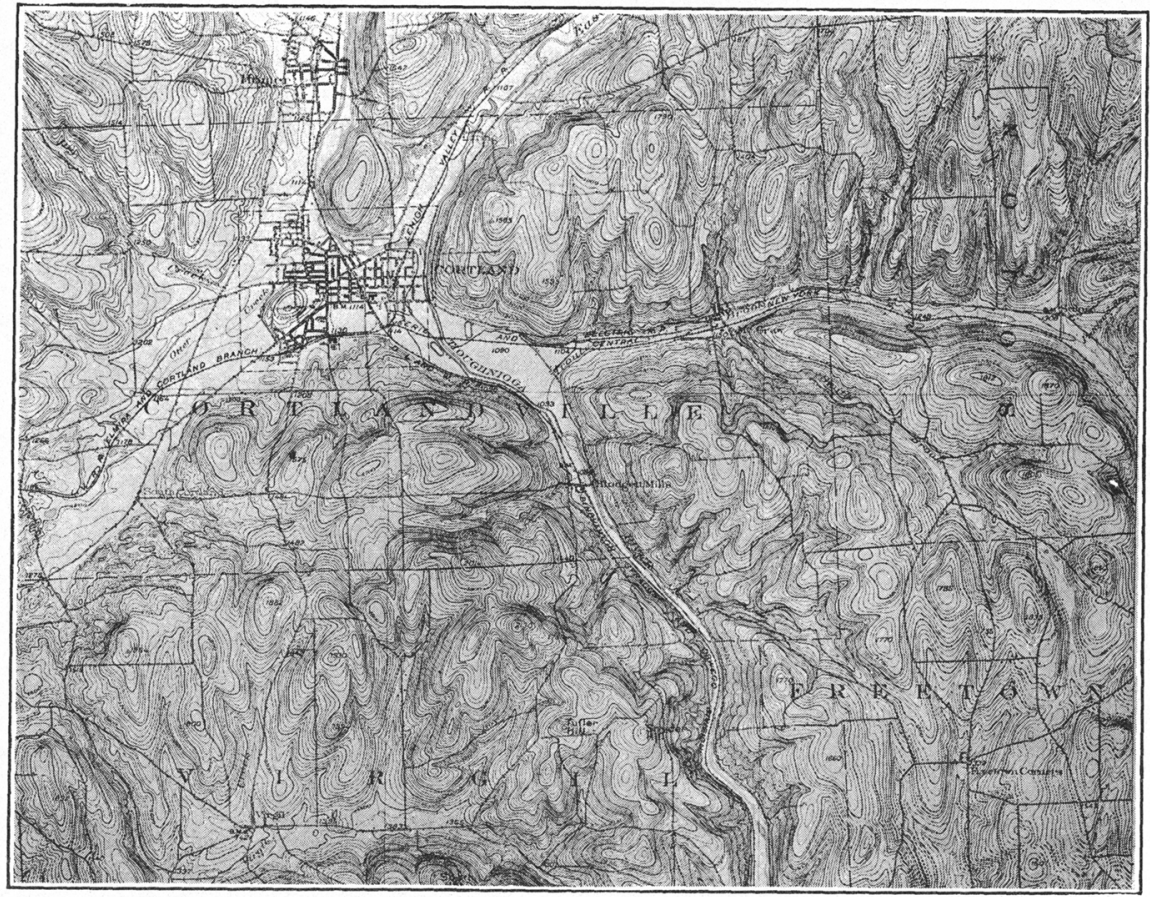

Figure 1. - The Diversion of the Tioughnioga Rivfer

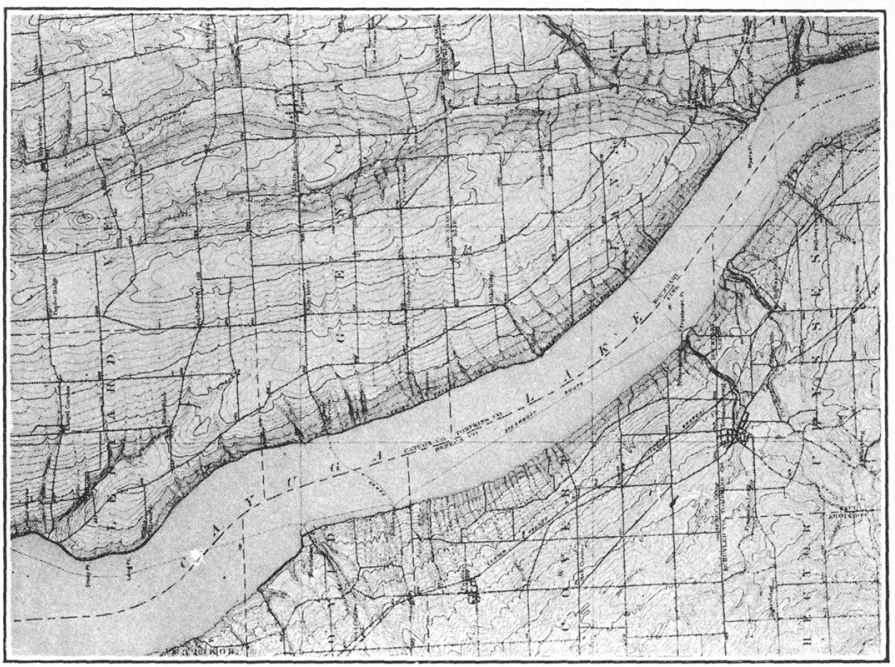

Figure 2.-The steepfente Slope of Caytga Lake Valley 
in which the streams tumble precipitously down the steepened slope as a series of rapids, cascades, and falls (figures 2 and 3 and plate 38 ). The maturity of the hanging valleys proves that a long time was required for their development at a baselevel not far from the 900 -foot level. There

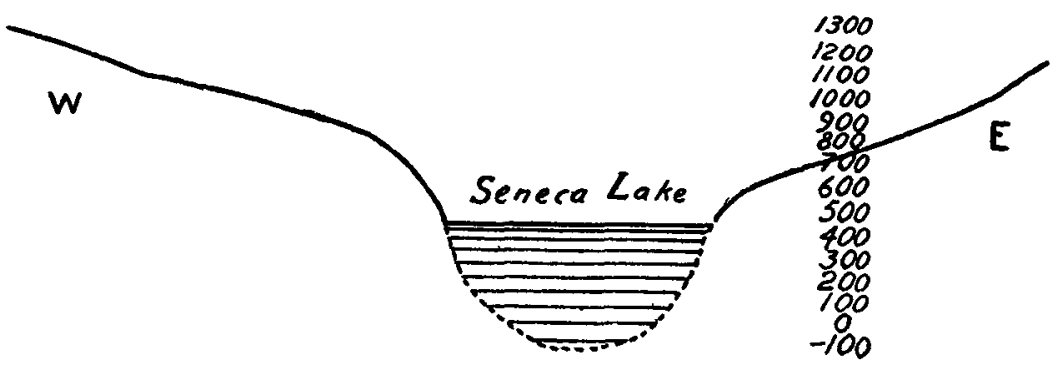

Figure 1.-Cross-section of Seneca Lake.

Three miles north of Watkins. Column of figures refers to elevation with reference to sealevel Vertical scale exaggerated about five times.

are two ages of gorges cut in the steepened slope, one distinctly postGlacial, the other, being both broader and deeper and partly filled with deposits made by the Wisconsin ice sheet, evidently antedating the advance of this ice sheet.

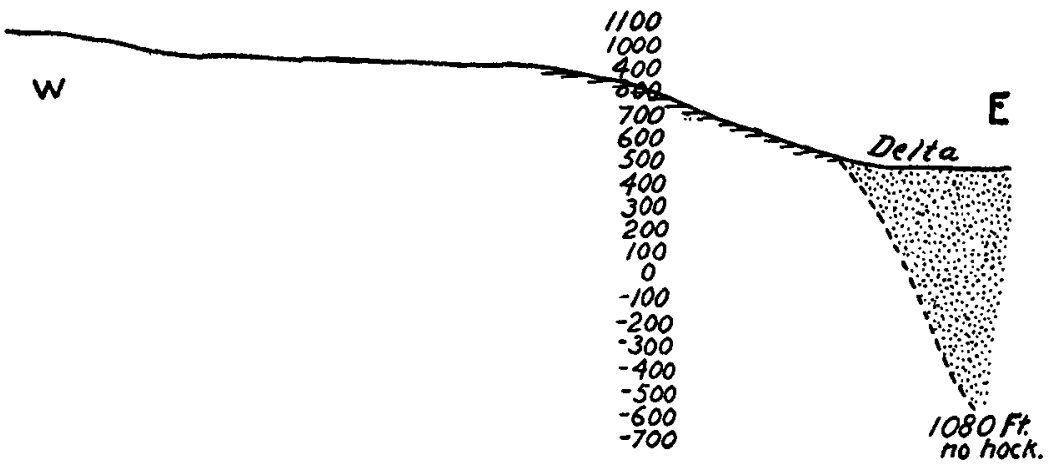

Fiaure 2.--Profile along Watkins Glen Creek.

Scale same as figure 1.

The headwaters of the hanging valleys are far less mature than the lower reaches, for from the headwaters the valleys broaden downstream, while the valley walls become less steep. A gorge condition exists in many of the headwater tributaries, and the valley walls are almost uniformly steep, indicating that active erosion was in prorress here when 
the new cycle was introduced by which the main valley bottoms were lowered.

Hanging valleys in the Tiougnioga trough.-The Tiougnioga valley, which extends southeastward from near Cortland across the Cortland and Harford topographic sheets, carries southward to the Susquehanna the headwaters of the Fall Creek drainage area, normally tributary to Cayuga lake* (see plate 39, figure 1). From near Cortland to a point about 3 miles south of Blodgett Mills the valley narrows, becoming there a deep, steep-sided, gorge-like valley, below which there is again a broadening. This narrow section is without doubt an old divide region across which the upper Fall creek has been diverted.

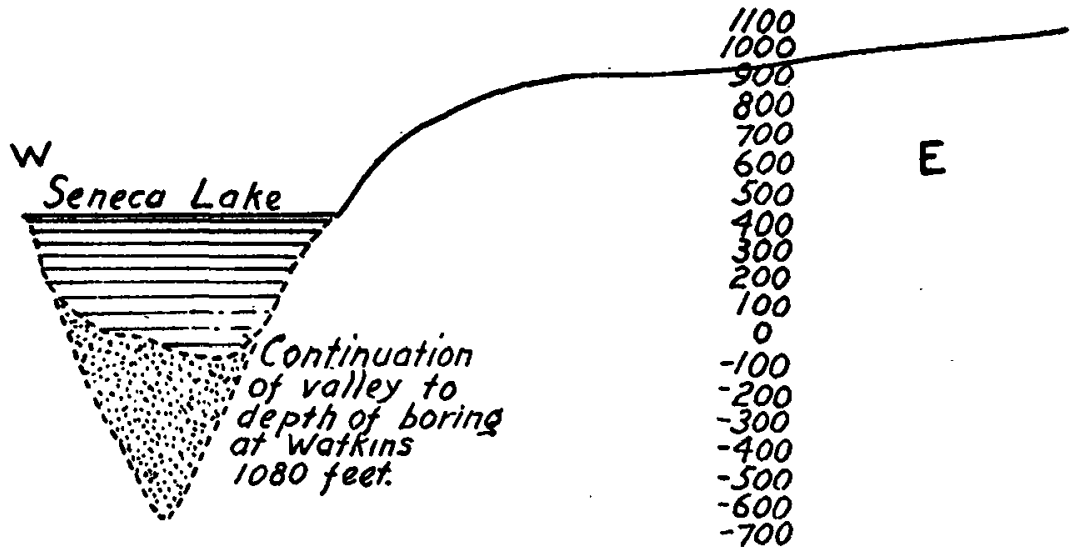

Fiatre 3.-Profile of Hector Falls Creek, Seneca Valley.

Two and one-half miles north of Watkins. Scale same as figure 1.

On either side of this valley, both above and below the narrow gorge, the tributaries occupy gorges cut in hanging valleys. The upper portions of these tributaries are in broad, mature valleys, while the lower portions are in rock-walled gorges 50 to 100 feet in depth, resembling in appearance the buried gorges in the Cayuga and Seneca troughs. In each case the gorge is cut in a rock bench extending across the mouths of hanging valleys. Viewed from the opposite side of the Tiougnioga valley, these tributary valleys are plainly seen to be hanging above the main valley, with the gorges cut in their bottoms.

That these gorges are not post-Glacial is proved by the presence in them of drift deposits and, in at least two cases, of buried sections so completely filled with drift that the present stream has been turned 
aside and forced to cut a narrower gorge apparently entirely of postGlacial age. While this condition of hanging valleys is present in a number of the tributaries, it is most typically illustrated in East Virgil creek, west of Messengerville on the Harford sheet, and in an unnamed creek on the east side of the valley about 2 miles south of Blodgett Mills on the Cortland sheet. It is in these two valleys that the buried gorge sections are found.

Other hanging valleys.-In a number of places on the Watkins Glen quadrangle there are hanging valleys, though in most cases not as typical as those described above. More or less completely drift-filled gorges cut in rock benches across the valley mouths, and changing upstream to broad, mature valleys are common. This condition is illustrated very clearly in a number of the tributaries to Cayuta creek between Van Etten and Waverly. In the work on this folio it has not been possible to carefully investigate each of the suspected hanging valleys, and therefore it can not be stated just how many such valleys there are; but enough have been proved to exist to demonstrate that the hanging valley condition is widespread in this region. Far the most perfect examples are those of the Cayuga and Seneca troughs, but the instances in the Tiougnioga and Cayuta valleys are just as certainly instances of hanging valleys. Extension of these studies to other areas and correlation of the results obtained will, it is hoped, warrant interpretation not now possible.

\section{LOWERED DIVIDES}

General conditions.-One of the most striking features in the topography of the divide region between the Saint Lawrence and Susquehanna drainage is the marked absence of well defined divides between the larger streams which head in this region. Along a number of valleys it is possible to pass from one drainage system to the other through open valleys in which the present divides are determined not by rock but by drift deposits. A similar condition is found between the headwaters of the larger tributaries on each side of the main divide; and even in the case of the smaller tributaries there is frequently a condition of lowered divides. In discussing this paper at the Geological Society meeting in Philadelphia Professor Davis applied the very descriptive name of "through valleys" to this condition of valleys connected across lowered divides.

Accompanying this condition there has been much diversion of drainage across the lowered divides, so that it is very frequently the case that the present divide does not coincide with an earlier position. This is proved by the fact that streams frequently head on drift deposits in a 
broadly open valley, flow toward a narrowing section of the valley, pass through a gorge with rock walls and drift floor, and thence on into another broader section. These conditions may best be understood by describing several specific instances.

Seneca and Cayuga valleys.-In both these valleys (plate 37 ) there is an open trough southward across the present divide, which is in drift; and in both cases one side, and in some cases both sides of the valley have precipitous sides. A canal and a railway have passed across the Seneca divide with moderate grade, and a railway with a somewhat steeper grade passes through the Cayuga trough. In these two valleys the topography does not demonstrate the exact location of the earlier divide

The Chemung near Elmira.-From Corning to Elmira there is a broad valley swinging northward past Horseheads, and followed by two railroads (see plate 40 ). The Chemung river leaves this valley near Big Flats and makes a cross-cut to Elmira behind a high mass of hills. This section of the valley is much narrower than the abandoned portion past Horseheads, and it flares both ways from a narrow gorge section, evidently the site of an old divide. No rock is encountered by the stream, and the valley is partly filled and clogged with glacial drift, including well defined moraines.

Near this region there are four smaller hills, with valleys behind them flaring both ways from a central divide, which bear a close resemblance to the valley followed by the Chemung. Two of these lie about 2 miles southwest of Elmira (see plate 41, figure 1), one about 2 miles northeast, and one about 2 miles northwest of Horseheads (see plate 40). If the plain of outwash gravels over which the Chemung flows had been built 100 feet higher, there would be in these cases an almost exact duplication of the conditions in the Chemung valley, only on a smaller scale (see plate 40).

Cayuta valley.-Next to the Chemung river, Cayuta creek is the longest stream on the Watkins Glen quadrangle. It is, however, joined by no large tributaries, and for most of the distance its divide is within from 2 to 4 miles of the creek. Its valley has two narrow, gorge-like sections, in each case with a broadening of the valley in both directions from the narrow portion (see plate 37). One of these narrow sections is about midway between Cayuta and Rodbourn and one between Van Etten and Waverly. The topography clearly indicates that the narrow sections were the sites of earlier divides, and that parts of three stream systems have been united to form a single creek. One portion was tributary to the Seneca valley, one flowed eastward past Spencer, and the third, as now, southward to the Chemung river at Waverly. This valley is fol- 


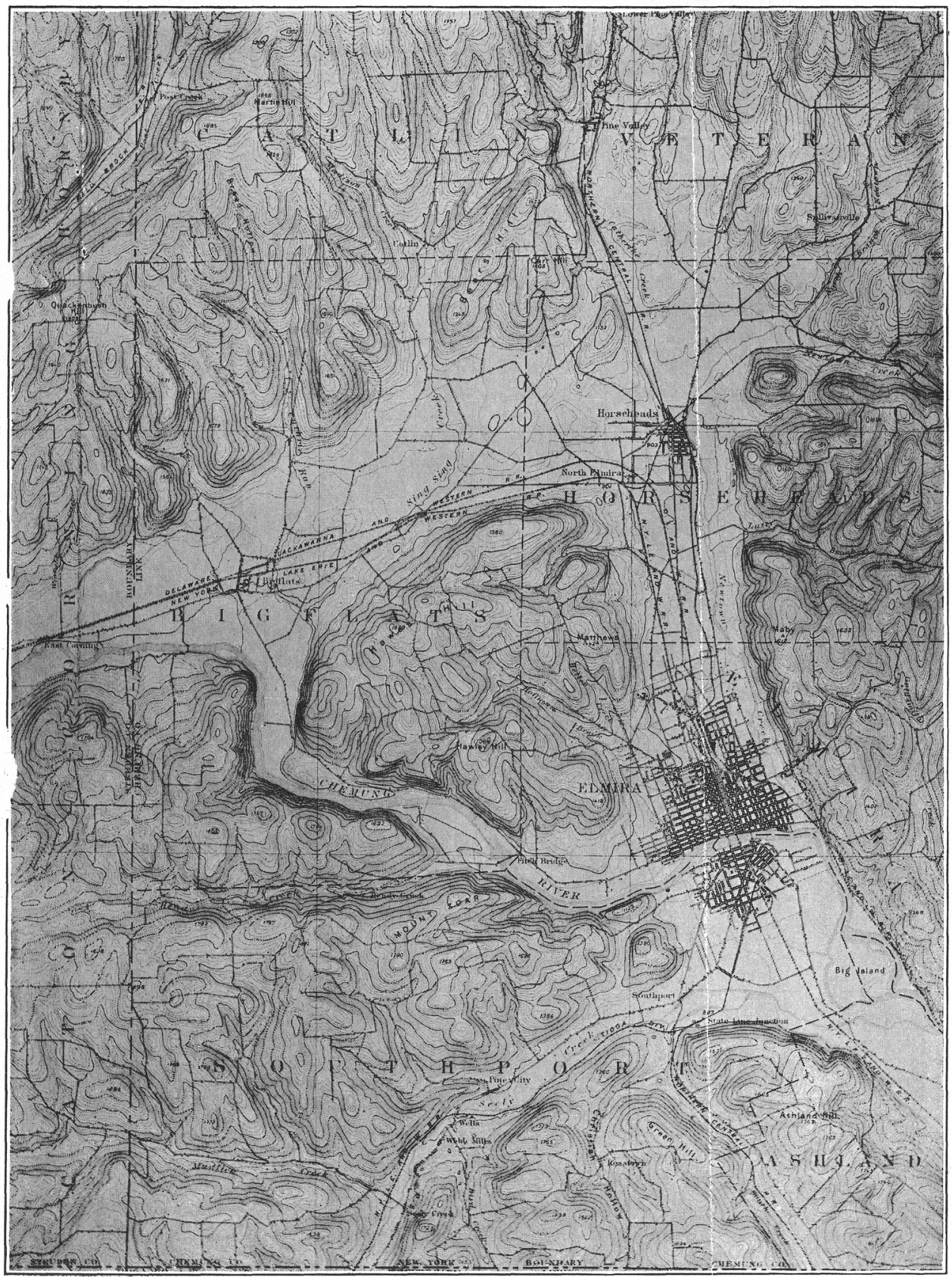

DIVERSION OF THE CHEMUNG RIVER NEAR ELMIRA; NEW YORK 


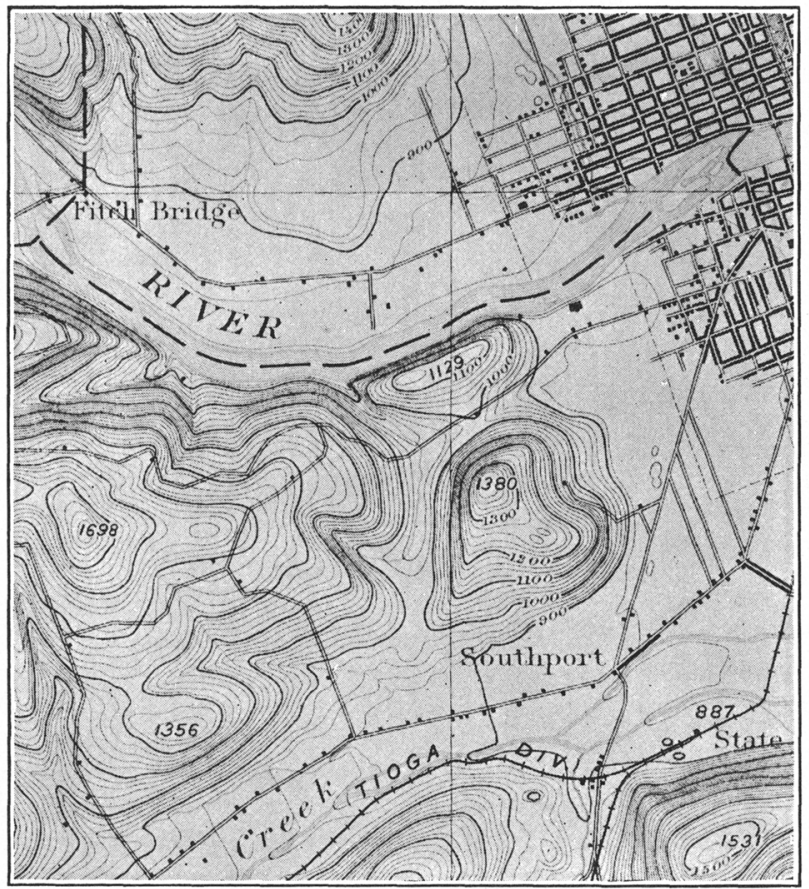

Figure 1.-Lowered Divides Southeast of Elmira

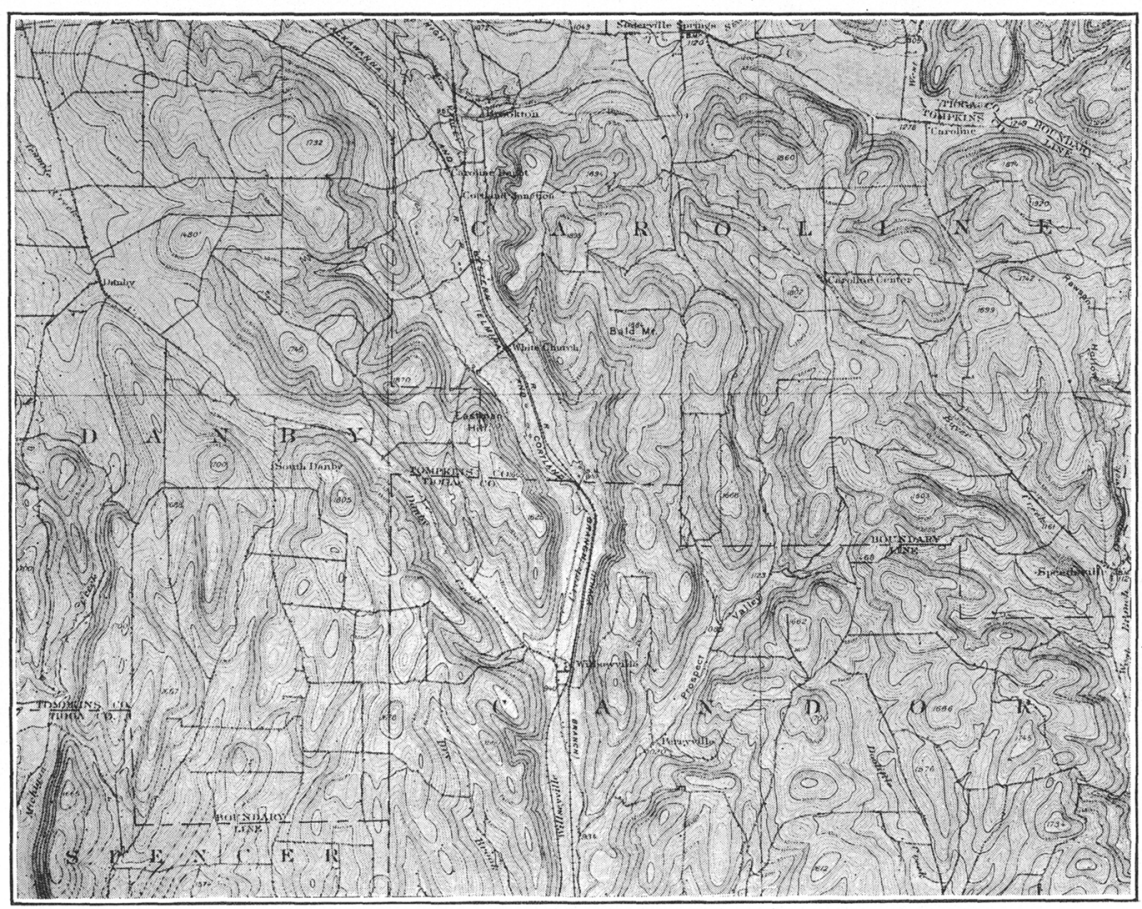

Figure 2.-The Willoseyville Valley 
lowed by the main line of the Lehigh Valley railroad, and toward the east, past Van Etten, by a branch of this railroad. 'The present divides are low drift masses, and any old divides that may have existed have been completely obliterated, so that no rock is encountered in the stream course.

Tiougnioga valley.-Carney* has shown that the headwaters of Fall creek, instead of following the broadening valley toward Ithaca, turn southward at Cortland into a narrowing valley, through a gorge section, evidently the site of an old divide, and thence into a broadening valley. As has been stated above, this doubly flaring valley has tributaries hanging well above the present valley bottom on both sides of the narrow section. Drift fills the valley, till and moraine occur on its sides, and no rock is encountered in its bottom, even in the narrowest part (see plate 39, figure 1).

Willseyville valley.-Between the head waters of Six Mile and Willsey ville creeks, on the Dryden sheet, there is a deep, gorge-like valley, with walls so steep that they are not cleared of forest (see plate 41 , figure 2). The valley bottom is occupied by extensive moraine accumulations, and no rock appears in it, nor any well defined divide, the waters at present parting in the moraine. Toward the narrow gorge portion the valley narrows from each side, indicating the location of a former divide. At present two railroads pass with easy grade through this peculiar valley. Tributary valleys, with bottoms below the level of the moraine filling of the main valley, enter it in the narrow gorge portion.

Other instances.-It would be possible to multiply the instances of this condition from the southern central portion of New York. For example, confining attention to the Watkins Glen quadrangle, Post creek, on the western side of the quadrangle southwest of Watkins (see plate 37), flows from a broad into a narrowing valley. There is no definite divide in the Burdett-Reynoldsville valley northeast of Watkins, nor between the upper Taghanic and Cayuta Lake valleys, nor the Pony Hollow and Butternut valleys (see plates 37 and 38). It may be said, in fact, that there is no single case of a well defined rock divide between the headwaters of the main branches of any of the larger streams on the Watkins Glen quadrangle.

Texas hollow.-This valley is one of the most peculiar in the Watkins Glen quadrangle (see plate 42 , figure 1). It is a deep valley with sides so steep that for the greater part of the distance the forest remains, and no road ascends to the upland; and it is so narrow at the botton. that, excepting at the ends, there are only a few small, poor farms. The 
valley broadens both ways from a narrow central portion, in which there is a low rock divide near the present divide, which is in drift. This " hollow" is therefore a double valley, with both a sloping bottom and flaring walls on each side of the divide. Its form is gorge-like, its walls remarkably straight and smooth, and its tributaries confined to small streams, which head on the very edge of the "hollow."

Such steep, smooth, straight valley walls, though nowhere on the Watkins Glen quadrangle as well developed as in Texas hollow, are, nevertheless, a common type of topography in this region (see plates 37 and 38). They are found, for example, south of both Watkins and Ithaca; in the Cayuta valley; near Elmira; in the valley southwest of Mecklenburg; and in many other places. Such valley walls are most perfectly developed in the neighborhood of lowered divides, and they occur in both north-south and east-west valleys.

Divides of smaller streams.-Many of the smaller headwaters are located in broad, cirque-like, upland valleys, whose divide crest commonly reaches elevations of from 1,500 to 1,800 feet. These upland valleys, which are decidedly mature in form, frequently have gorges cut in their bottoms, and in some cases are breached by gorges. The best and most typical instance of this so far observed is on the very edge of the Watkins sheet, almost due west of Watkins. A very perfect cirque-like valley faces eastward, and the smooth, regular divide is cut completely across by the gorge of a west-llowing stream.

From this condition there is every stage to such cases of complete obliteration of divides as those described above. Southwest of Van Etten, for instance, the divide between Baker and Wyncoop creeks (see plate 42 , figure 2), is a low, flat-bottomed valley, bounded by smooth, straight-sided, precipitous walls. Just south of Breesport, at the head of Baldwin Creek valley, the divide is so low that if the gravel plain that was built at the closing stages of the ice occupation could be removed Newtown creek could be easily diverted across it. These instances may serve as types which could be added to if it were necessary ; and it should be noted that both in the large and small valleys there are instances of lowered divides extending in all directions.

Present stream courses.-The facts stated above prove conclusively that there has been a widespread condition of divide lowering in the region under consideration. Exactly the extent to which this lowering has been carried in the major valleys is not certain because of the drift filling; but in some of the smaller valleys the divide lowering has not gone so far that the glacial deposits have obliterated the rock divide.

Whatever the cause for the lowering of the divides, the present stream 
BULL. GEOL. SOC. AM.

VOL. 16,1904 , PL. 42

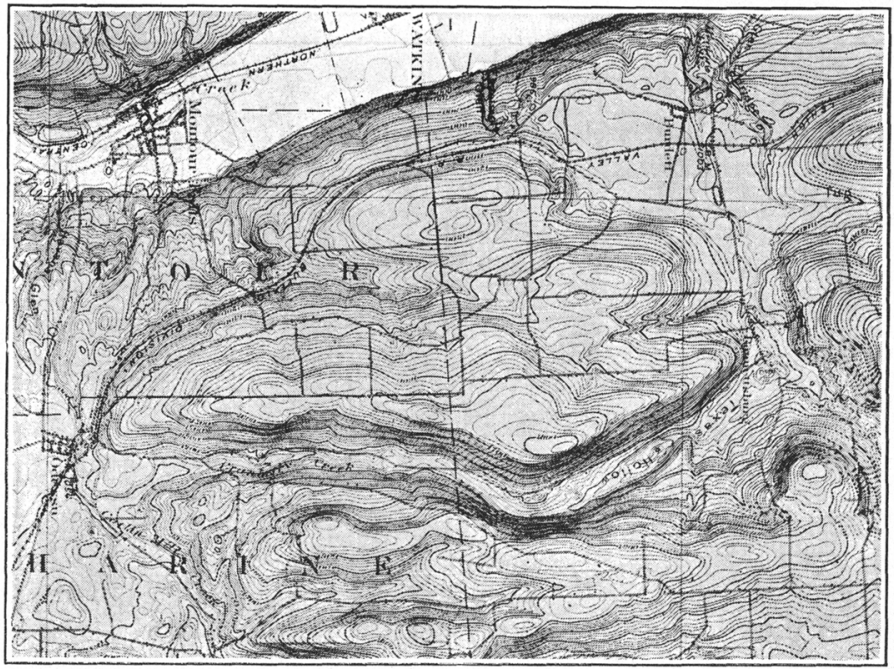

Figure: 1.--T'trixas Hounow Trough

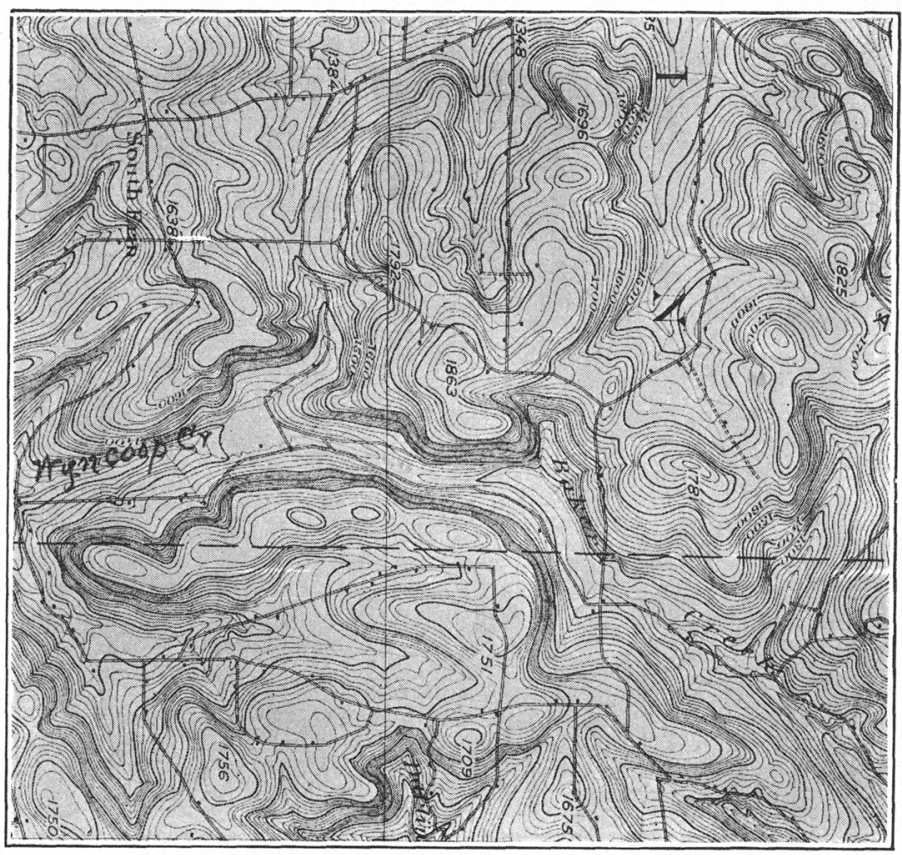

Figure 2.-Divide between Baker and Wyncoop Creeks

TEXAS HOLLOW TROUGH AND DIVIDE BETWEEN BAKER AND WYNCOOP CREEKS 

courses, which so often lead across the sites of ancient divides, are due to the fact that glacial deposits have so graded the valleys as to make streams of two systems unite in a single course. For instance, in both Post Creek and Pony Hollow valleys, moraines form the present divides, and outwash gravel plains supply a grade down which the streams flow across ancient divide sites. The same is true of Cayuta creek. The course of the Chemung west of Elmira is also determined by outwash gravels, which spread fan-shaped from the neighborhood of Horseheads, both toward Elmira and Big Flats, making the part of the valley near Horseheads higher than those parts farther away from the moraines, during the building of which the outwash gravels were supplied.

By these morainic and outwash gravel deposits the present divides have to a large degree been determined, and, as a result of the changes thus brought about, the drainage of this divide region has been profoundly altered; but without a previous lowering of the divides these decided changes in drainage would not have been possible.

\section{INTERPRETATION}

\section{STATEMENT OF HYPOTHESES}

Three different hypotheses suggest themselves as possible explanations of the drainage peculiarities described above: (1) Ice erosion; (2) erosion by ice-born streams; and (3) headwater erosion, lowering divides and capturing opposing headwaters. The ice-erosion hypothesis must include not only the last ice advance, but also earlier ice advances, of which, however, there is no direct evidence so far discovered in this region. The same is true of the hypothesis of ice born streams; and, in addition, the possibility of water erosion during both the advance and retreat of each ice sheet must be considered. These hypotheses will be considered separately.

\section{ICE-EROSION HYPOTHESIS}

A number of facts are opposed to this hypothesis. In the first place, as has been stated elsewhere,* there is in this region definite evidence of weak ice erosion during the last ice ad vance. Residually decayed rock abounds in the southern half of the quadrangle, and some is present even on the margin of Cayuga lake below the edge of the steepened slope. Moreover, gorges cut in the steepened slope have not been erased nor distinctly modified in form by ice erosion. If it is true that the last ice advance in a main valley like the Cayuga trough did not perform marked

\footnotetext{
* R. S. Tarr : American Geologist, vol. xxxiii, 1901, p. 286; Journal of Geology, vol. xiii, 1905, p. 160.

XXXII-BULL. Geol. Soc. AM., VoL. 16, 1904
} 
erosion, it would seem certain that ice erosion in less favorably situated valleys could not have been great. Furthermore, some of the best instances of "through valleys" are south of the zone of most active ice erosion and in a region where residually decayed rock abounds.

The great number of instances of lowered divides and steepened slopes, in valleys of all sizes and extending in all directions, would demand an altogether remarkable irregularity of ice movement. This may be illustrated by the case of the Chemung west of Elmira (see plate 40). To account for its lowered divide, ice would have to move either east or west; but at the end of its narrow section, 2 miles southwest of Elmira, are two small hills with valleys similar to that of the Chemung, one extending north and south, the other east and west (see plate 41, figure 1). These three valleys are apparently of the same origin, for, barring size, their characteristics are essentially the same. To account for them by ice erosion would require ice movement in two valleys at right angles and all within an area of a square mile.

The flaring of the valleys in two directions from a narrow central portion hardly seems a probable result of ice erosion. In Texas hollow, for example, the same characteristics of valley wall form extend both north and south of the narrowest part. It is a question whether, in the case of ice passing through a narrow divide gap, its movement would not be checked by the narrowing valley and a tendency toward stagnant conditions be brought about. Especially would this seem to be the case where the valley extended at an angle to the general ice motion, as was the case in a large number of instances in this region, including Texas hollow.

There are some cases where ice erosion by the Wisconsin ice sheet is entirely out of the question. This is best illustrated in the Tiougnioga valley, where, on each side of the narrow gorge portion, there is a condition of hanging valleys with gorges in their bottoms, which were developed before the Wisconsin ice advanced. In the Willseyville and Cayata valleys also there are tributary valleys developed after the lowered divide conditions were brought into existence, and therefore, since they are drift filled, before the last ice advance. Since this has been proved to be true of several valleys, it seems probable that it is true also of others, concerning which such definite proof has not yet been found.

Altogether the facts weaken the ice-erosion hypothesis, and in some of the valleys the evidence is definite that their condition is not due to ice erosion during the Wisconsin ice advance. Facts have not been discovered which disprove the hypothesis that these valley conditions are due to an earlier ice advance; and, although no evidence of such earlier 
ice advances in this region has been discovered so far, that hypothesis must still be held as a working hypothesis in future studies.

\section{ICE-BORN STREAM-EROSION HYPOTHESIS}

Wherever positive evidence could be discovered in this area the erosion of streams associated with the melting of the Wisconsin ice sheet was found to be very slight, in most cases amounting merely to a notching of the drift deposits. The ice-born streams were depositing rather than eroding profoundly. That the peculiarities of the valleys described above are not in any important degree due to erosion by streams flowing at the closing stages of the last ice advance is demonstrated by the fact that practically all the valleys contain undisturbed morainic deposits which could not have escaped destruction if there had been marked erosion by ice-born streams.

This form of evidence does not, however, eliminate the possibility of water erosion connected with the advance of the Wisconsin ice; but in certain cases, like the Tiougnioga, Cayuta, and Willseyville valleys, the presence of older buried tributaries does eliminate this hypothesis for these par ticular cases, and, since they are analogous to the others, weakens the hypothesis that they are due to water erosion during the advance of the Wisconsin ice sheet.

The great number of instances, extending in all directions, and of all sizes, would call for a vast amount of water erosion under very variable conditions. I find it exceedingly difficult, for example, to postulate any conceivable set of conditions by which ice-born stream erosion could possibly cut the complex of channels near Elmira and Horseheads, described above. Moreover, it does not seem possible that water erosion of overflow or marginal type could form the doubly flaring condition of Texas Hollow valley, nor the Chemung valley west of Elmira, nor a score of other similar valleys.

Even if several ice advances have been involved, and a large number of ice front positions are postulated to account for these peculiar valleys, the efficiency of glacially supplied streams to form such topographic features is questionable. While the ice was advancing and receding from this hilly region its front could not at any time have long stood on the divides, and while it did, judging from the history recorded at the closing stages of the last ice advance, deposition would seem to have been the rule, not erosion. When the ice fronts stood north of the divides there were marginal lake conditions, and the inefficiency of such a river as the Niagara or the Saint Law rence to form a rock gorge does not lend much support to the hypothesis that the overflows of the 
glacial lakes were capable of such profound erosion as that necessary to account for the many deep, long cuts in the divide region of southern New York.

From the facts, as indicated in the above outline, it is evident that the peculiar valley conditions of this area are not the result of the action of streams supplied by the melting of the Wisconsin ice sheet, and that in several instances, at least, the conditions were brought about long before the advent of this ice sheet. The hypothesis that these conditions were brought into existence by possible earlier ice advances is weakened by several facts aside from the fact that studies in this region have not yet revealed any evidence of the presence of former ice sheets. It must, nevertheless, remain as a working hypothesis until either some other explanation is established or this one eliminated.

\section{HEADWATER-EROSION HYPOTHESTS}

On this hypothesis the assumption is that streams gnawing at their - headwaters have in many cases so lowered the divides as to permit complete diversion of streams across these divides when the valleys have been graded up by glacial deposits. By this hypothesis it is further assumed that the gnawing back at the headwaters often caused an encroachment of one stream system on the opposing system and the consequent capture of the headwaters of rival streams in favorable cases. At the present stage of the study it does not seem wise to enter into the consideration of why this headwater erosion may have been in progress nor exactly how it was operating. Further study over a wider area may make this consideration desirable at a later time.

The difficulties in the way of accepting either ice erosion or ice-born stream erosion as an explanation of the peculiar valley conditions of this area may be considered as favorable to the head water-erosion hypothesis. Moreover, many of the facts opposing the rival hypotheses directly support headwater erosion. The doubly flaring condition of the valleys is a type of form that such headwater erosion would be expected to produce.

If two streams heading in the narrow part of the Chemung valley west of Elmira were lowering their divides, just such a condition as exists west of Elmira would be produced. This process of divide lowering seems to have been in progress behind the small hills 2 miles southwest of Elmira and behind those northeast and northwest of Horseheads. In fact, in many places there are lowered divides in all stages of lowering, from simple notching of the divides to such complete reduction as to permit burial beneath glacial deposits. 
That before the glacial period stream erosion was vigorous throughout this divide region is evident from the steep slopes of the valley sides both in the small and the large valleys and from the presence of gorges in many of the valleys. Neither glacial erosion nor ice-born stream erosion, even with the maximum possible number of ice advances, can possibly be appealed to in explanation of all these steep valley slopes, and since they harmonize in form with the steep slopes of the lowered divides they lend support to the hypothesis of headwater erosion for the lowered divides.

On the other hand, as has been suggested to the author by both Doctor Gilbert and Professor Davis, such a condition of "through valleys," while not uncommon in regions of faulting or in regions of inclined and varied strata, has not been described in regions of horizontal strata outside the glacial belt. I have examined several hundred sheets of the United States Geological Survey topographic map in regions outside the glaciated area without finding even an approach to the conditions described above. 'To this difficulty must be added that of understanding just how divide lowering, operating excessively in some valleys, has produced no effect whatsoever in neighboring headwaters.

DISCORDANCE OF THE CAYUGA AND SENECA VALLEYS

The lowering of the divides is in no way related to rejuvenation resulting from the deepening of the Cayuga and Seneca valleys, for it extends outside of their drainage areas, and, even where developed in the headwaters of tributaries to these two valleys, occurs in valleys hanging high above the bottom of the main lake troughs. The upper parts of these hanging valleys are broad, deep, and steep-sided, with the main divides obliterated by erosion and glacial deposit, but with the lower ends terminating on the edge of a steepened slope notched only by small gorges. This fact favors the theory of glacial erosion for the basins of these two lakes, although other facts, stated in another paper, oppose it.

\section{Conclusions}

The one conclusive result of the studies so far made toward the solution of this drainage problem is that, in several typical instances, the phenomenon of lowered divides antedates the last or Wisconsin ice invasion. The establishment of this fact is the excuse for the present paper.

In all other respects this paper must stand as an unfinished study, in which certain observations are recorded and difficulties opposing each of three hypotheses pointed out. 
242 R. S. TARR-DRAINAGE FEATURES OF CENTRAL NEW YORK

The complete solution of the problem has not yet been reached, but some progress has been made; and, since others as well as the writer are at work on this complex field, this report of progress is made in the hope that it may serve as a slight contribution toward the ultimate unraveling of the events which have caused the peculiarities of drainage in this region. 


$$
\text { - }
$$

